\title{
NUMERICAL SOLUTION OF A SYSTEM OF SINGULAR INTEGRAL EQUATION WITH HILBERT AND CAUCHY KERNELS
}

In the paper a specific system of first kind singular integral equations with the Hilbert and Cauchy kernels arising when solving some problems of electrostatics and electrodynamics is studied. The method of discrete singularities is applied for constructing its discrete mathematical model, which is a system of $n$ linear algebraic equations. Under the additional smoothness assumptions on the right-hand parts of the equations of the initial system and regularity assumptions on the kernels of the integrals in them the obtained system of linear algebraic equations is proved to admit a unique solution for $n$ sufficiently large. The rate of convergence of the solution of the discrete problem to the exact solution of the system of singular integral equations is estimated.

Key words: system of singular integral equations, method of discrete singularities, Hilbert kernel, Cauchy kernel, discrete model.

\section{Т. С. ПОЛЯНСЬКА, О. О. НАБОКА \\ ЧИСЕЛЬНЕ РОЗВ'ЯЗАННЯ СИСТЕМИ СИНГУЛЯРНИХ ІНТЕГРАЛЬНИХ РІВНЯНЬ 3 ЯДРАМИ КОШІ І ГІЛБЕРТА}

В роботі вивчається система сингулярних інтегральних рівнянь першого роду з ядрами Коші і Гілберта спеціального виду, що виникає, зокрема, при розв'язанні задач електростатики та електродинаміки. На основі методу дискретних особливостей побудовано дискретну математичну модель цієї системи, що має вигляд системи $n$ лінійних алгебраїчних рівнянь. Доведено, що за додаткових умов гладкості на праві частини та регулярні ядра вихідних рівнянь отримана система лінійних алгебраїчних рівнянь має при достатньо великих $n$ єдиний розв'язок. Дана оцінка швидкості збіжності розв'язку дискретної задачі до точного розв'язку системи сингулярних інтегральних рівнянь. модель.

Ключові слова: система сингулярних інтегральних рівнянь, метод дискретних особливостей, ядро Гілберта, ядро Коші, дискретна

\section{Т. С. ПОЛЯНСКАЯ, Е. А. НАБОКА \\ ЧИСЛЕННОЕ РЕШЕНИЕ СИСТЕМЫ СИНГУЛЯРНЫХ ИНТЕГРАЛЬНЫХ УРАВНЕНИЙ С ЯДРАМИ КОШИ И ГИЛЬБЕРТА}

В работе изучается система сингулярных интегральных уравнений первого рода с ядрами Коши и Гильберта специального вида, возникающая, в частности, при решении задач электростатики и электродинамики. На основе метода дискретных особенностей построена дискретная математическая модель этой системы, которая имеет вид системы $n$ линейных алгебраических уравнений. Доказано, что если правые части уравнений исходной системы удовлетворяют дополнительным условиям гладкости, а ядра являются регулярными, полученная система линейных алгебраических уравнений имеет при достаточно больших $n$ единственное решение. Дана оценка скорости сходимости решения дискретной задачи к точному решению системы сингулярных интегральных уравнений.

Ключевые слова: система сингулярных интегральных уравнений, метод дискретных особенностей, ядро Гильберта, ядро Коши, дискретная модель.

Introduction. The method of discrete singularities is an efficient method for solving singular integral equations as well as systems of such equations arising in applications, for instance, when solving the applied problems of aerohydrodynamics, electrodynamics, elasticity theory, problems of mathematical physics [1,2]. A detailed study of numerical solution of a single singular integral equation with the Hilbert kernel is presented in [3]. In [4] the method of discrete singularities is applied for solving the problem of diffraction on a grate which gives rise to a singular integral equation with the Cauchy kernel.

In the present paper a specific system of the first kind singular integral equations with Hilbert and Cauchy kernels (for all indices) is studied. The necessity in substantiating the method of discrete singularities for a system of this type arises in particular when solving problems of electrostatics and electrodynamics $[5,6]$.

Setting the problem for a system of singular integral equations (SIE). We study the following system of SIE:

$$
\left\{\begin{aligned}
& \frac{1}{\pi} \int_{-1}^{1} \frac{u_{i}(\tau) \rho_{\lambda_{i}}(\tau)}{\tau-t} d \tau+\sum_{k=1}^{m_{1}} \frac{1}{\pi} \int_{-1}^{1} Q_{i k}(t, \tau) u_{k}(\tau) \rho_{\lambda_{k}}(\tau) d \tau+ \\
&+\sum_{k=m_{1}+1}^{m} \frac{1}{2 \pi} \int_{0}^{2 \pi} Q_{i k}(t, \varphi) u_{k}(\varphi) d \varphi=f_{i}(t),|t|<1, \quad i=1, \ldots, m_{1} ; \\
& \frac{1}{2 \pi} \int_{0}^{2 \pi} \operatorname{ctg} \frac{\varphi-\theta}{2} u_{i}(\varphi) d \varphi+\sum_{k=1}^{m_{1}} \frac{1}{\pi} \int_{-1}^{1} Q_{i k}(\theta, \tau) u_{k}(\tau) \rho_{\lambda_{k}}(\tau) d \tau+ \\
&+\sum_{k=m_{1}+1}^{m} \frac{1}{2 \pi} \int_{0}^{2 \pi} Q_{i k}(\theta, \varphi) u_{k}(\varphi) d \varphi=f_{i}(\theta), \quad i=m_{1}+1, \ldots, m,
\end{aligned}\right.
$$

(C) T. S. Polyanskaya, O. O. Naboka, 2020 
for the unknown functions $u_{1}(\tau), \ldots, u_{m_{1}}(\tau), u_{m_{1}+1}(\varphi), \ldots, u_{m}(\varphi)$. The first integrals in the left-hand parts of the equations in (1) are improper and are considered in the sense of their Cauchy principal value.

In (1) $\lambda_{k}, k=1, \ldots, m_{1}$ are the indices of the solution $y_{k}(\tau)=u_{k}(\tau) \rho_{\lambda_{k}}(\tau)$, such that $\lambda_{k}=-1$ for $1 \leq k \leq l_{1}$, $\lambda_{k}=0$ for $l_{1}+1 \leq k \leq l_{2}, \lambda_{k}=1$ for $l_{2}+1 \leq k \leq m_{1}$; the corresponding weights are defined by the formulae:

$$
\rho_{-1}(\tau)=\sqrt{1-\tau^{2}}, \quad \rho_{0}(\tau)=\sqrt{\frac{1-\tau}{1+\tau}}, \quad \rho_{1}(\tau)=\frac{1}{\sqrt{1-\tau^{2}}}
$$

$f_{i}(\theta), Q_{i k}(t, \varphi), Q_{i k}(\theta, \tau), Q_{i k}(\theta, \varphi)$ are given functions $2 \pi$-periodic in $\theta$ and $\varphi$. We assume that $f_{i}(t) \in C_{[-1,1]}^{\mu, \gamma}$ for $i=1, \ldots, m_{1}$ and $f_{i}(\theta) \in C^{\mu, \gamma}$ for $i=m_{1}+1, \ldots, m$ and the kernels $Q_{i k}(i, k=1, \ldots, m)$ possess the same properties in each variable uniformly with respect to another variable. The notation $C^{\mu, \gamma}$ stands for the class of $\mu$ times continuously differentiable functions which $\mu$-th derivatives satisfy the Holder condition with the exponent $\gamma(0<\gamma \leq 1)$.

Let $\vec{u}=\left(u_{i}\right)_{i=1}^{m}$ with $u_{i}=u_{i}(\tau)$ for $1 \leq i \leq m_{1}$, and $u_{i}=u_{i}(\varphi)$ for $m_{1}+1 \leq i \leq m$. Consider the following operators:

$$
\left(A_{\lambda} u\right)(t)=\frac{1}{\pi} \int_{-1}^{1} \frac{u(\tau) \rho_{\lambda}(\tau)}{\tau-t} d \tau ; \quad(\Gamma u)(\theta)=\frac{1}{2 \pi} \int_{0}^{2 \pi} \operatorname{ctg} \frac{\varphi-\theta}{2} u(\varphi) d \varphi
$$

$\widehat{A} \vec{u}=\vec{w}=\left(w_{k}\right)_{k=1}^{m}$, where $w_{k}(t)=\left(A_{\lambda_{k}} u_{k}\right)(t)$ for $1 \leq k \leq m_{1}$, and $w_{k}(\theta)=\left(\Gamma u_{k}\right)(\theta)$ for $m_{1}+1 \leq k \leq m$

$$
\begin{gathered}
\widehat{Q} \vec{u}=\left(\sum_{k=1}^{m} Q_{i k} u_{k}\right)_{i=1}^{m} \text { with }\left(Q_{i k} u_{k}\right)(\xi)=\frac{1}{\pi} \int_{-1}^{1} Q_{i k}(\xi, \tau) u_{k}(\tau) \rho_{\lambda_{k}}(\tau) d \tau \text { for } 1 \leq k \leq m_{1}, \text { and } \\
\left(Q_{i k} u_{k}\right)(\xi)=\frac{1}{2 \pi} \int_{0}^{2 \pi} Q_{i k}(\xi, \varphi) u_{k}(\varphi) d \varphi \text { for } m_{1}+1 \leq k \leq m
\end{gathered}
$$

We also introduce the vector function $\vec{f}=\left(f_{i}\right)_{i=1}^{m}$, where $f_{i}=f_{i}(\xi)$ for $1 \leq i \leq m$. Here and below $\xi=t$ for $1 \leq i \leq m_{1}$, and $\xi=\theta$ for $m_{1}+1 \leq i \leq m$.

Using the operator notations given above system (1) is reduced to the form:

$$
(\widehat{A}+\widehat{Q}) \vec{u}=\vec{f} .
$$

System (3), and, hence, system (1), is assumed to have a unique solution, which satisfies the following auxiliary conditions:

$$
\left\{\begin{array}{c}
\frac{1}{\pi} \int_{-1}^{1} u_{k}(\tau) \frac{d \tau}{\sqrt{1-\tau^{2}}}=0, \quad k=l_{2}+1, \ldots, m_{1} \\
\frac{1}{2 \pi} \int_{0}^{2 \pi} u_{k}(\varphi) d \varphi=0, \quad k=m_{1}+1, \ldots, m
\end{array}\right.
$$

Moreover, for the solutions to system (1) the following conditions need to hold, which are in themselves the necessary conditions of the system solvability:

$$
\left\{\begin{array}{l}
\frac{1}{\pi} \int_{-1}^{1}\left[f_{i}(t)-\sum_{k=1}^{m}\left(Q_{i k} u_{k}\right)(t)\right] \frac{d t}{\sqrt{1-t^{2}}}=0, \quad i=1, \ldots, l_{1} \\
\frac{1}{2 \pi} \int_{0}^{2 \pi}\left[f_{i}(\theta)-\sum_{k=1}^{m}\left(Q_{i k} u_{k}\right)(\theta)\right] d \theta=0, \quad i=m_{1}+1, \ldots, m .
\end{array}\right.
$$

In the physical applications the functions $f_{i}(\xi), Q_{i k}(\xi, \tau)$ and $Q_{i k}(\xi, \varphi)$ are such that for all values of $k$ and any $\zeta$ the following holds:

$$
\begin{aligned}
& \int_{-1}^{1} f_{i}(t) \frac{1}{\sqrt{1-t^{2}}} d t=0, \quad \int_{-1}^{1} Q_{i k}(t, \zeta) \frac{1}{\sqrt{1-t^{2}}} d t \equiv 0 \quad \text { for } \quad 1 \leq i \leq m_{1} \\
& \int_{0}^{2 \pi} f_{i}(\theta) d \theta=0, \quad \int_{0}^{2 \pi} Q_{i k}(\theta, \zeta) d \theta \equiv 0 \quad \text { for } \quad m_{1}+1 \leq i \leq m .
\end{aligned}
$$

Conditions (6) then imply that (5) holds for any vector functions $\vec{u}=\left(u_{i}\right)_{i=1}^{m}$ and does not provide any additional 
limitations on the class of solutions to (1).

Discretization of the system of SIE. Before proceeding to discretizing system (1) we introduce interpolation polynomials we use throughout the paper.

Let $\left\{q_{n}^{(\lambda, 1)}(t)\right\}_{n=0}^{\infty}$ be a system of polynomials orthogonal in $L_{2}[-1,1]$ with the weight $\rho_{\lambda}(t)$, and let $\left\{t_{r}^{(\lambda, n)}\right\}_{r=1}^{n}$ be the roots of the polynomial $q_{n}^{(\lambda, 1)}(t)$. As it is shown in [7] for $\rho_{\lambda}(t)$ given by (2) the polynomials $q_{n-\lambda}^{(\lambda, 2)}(t)=\left(A_{\lambda} q_{n}^{(\lambda, 1)}\right)(t)$ are orthogonal in $L_{2}[-1,1]$ with the weight $\rho_{\lambda}^{-1}(t)$. Denote by $\left\{t_{o p}^{(\lambda, n)}\right\}_{p=1}^{n-\lambda}$ the roots of $q_{n-\lambda}^{(\lambda, 2)}(t)$.

Below we use the following system of polynomials:

$$
\begin{gathered}
q_{n}^{(1,1)}(t)=T_{n}(t), \quad q_{n-1}^{(1,2)}(t)=U_{n-1}(t), \quad\left\{t_{r}^{(1, n)}\right\}_{r=1}^{n}=\left\{\cos \frac{2 r-1}{2 n} \pi\right\}_{r=1}^{n},\left\{t_{o p}^{(1, n)}\right\}_{p=1}^{n-1}=\left\{\cos \frac{p \pi}{n}\right\}_{p=1}^{n-1} ; \\
q_{n}^{(0,1)}(t)=\frac{T_{n+1}(t)-T_{n}(t)}{t-1}, q_{n}^{(0,2)}(t)=-U_{n}(t)+U_{n-1}(t), \quad\left\{t_{r}^{(0, n)}\right\}_{r=1}^{n}=\left\{\cos \frac{2 r \pi}{2 n+1}\right\}_{r=1}^{n},\left\{t_{o p}^{(0, n)}\right\}_{p=1}^{n}=\left\{\cos \frac{2 p-1}{2 n+1} \pi\right\}_{p=1}^{n} ; \\
q_{n}^{(-1,1)}(t)=U_{n}(t), q_{n+1}^{(-1,2)}(t)=-T_{n+1}(t), \quad\left\{t_{r}^{(-1, n)}\right\}_{r=1}^{n}=\left\{\cos \frac{r \pi}{n+1}\right\}_{r=1}^{n},\left\{t_{o p}^{(-1, n)}\right\}_{p=1}^{n+1}=\left\{\cos \frac{2 p-1}{2 n+2} \pi\right\}_{p=1}^{n+1},
\end{gathered}
$$

where $T_{n}(t)=\cos (n \arccos t), \quad U_{n}(t)=\frac{\sin (n \arccos t)}{\sin (\arccos t)}$ are the Chebyshev polynomials of the first and second kind respectively.

Let $\left(L_{n}^{(\lambda, 1)} v\right)(t)$ be the Lagrange interpolation polynomial for the function $v(t)$ with the nodes $\left\{t_{r}^{(\lambda, n)}\right\}_{r=1}^{n}$, and let $\left(L_{n-\lambda}^{(\lambda, 2)} v\right)(t)$ be its Lagrange interpolation polynomial with the nodes $\left\{t_{o p}^{(\lambda, n)}\right\}_{p=1}^{n-\lambda}$.

We introduce also trigonometric interpolation polynomials for the function $v(t)$. Consider a unit circle centered at the origin. Assume that it is separated into $2 n+1$ equal arcs by the points which angular coordinates are $\left\{\varphi_{k}^{(n)}\right\}_{k=0}^{2 n}$. Denote $\left\{\varphi_{o j}^{(n)}\right\}_{j=0}^{2 n}$ the angular coordinates of the centers of the $\operatorname{arcs} \varphi_{j}^{(n)} \varphi_{j+1}^{(n)}, j=0, \ldots, 2 n\left(\varphi_{2 n+1}^{(n)}=\varphi_{0}^{(n)}\right)$. Let $\left(P_{n}^{(1)} v\right)(\varphi)$ be the trigonometric interpolation polynomial for the function $v(t)$ with the nodes $\left\{\varphi_{k}^{(n)}\right\}_{k=0}^{2 n}$, whereas $\left(P_{n}^{(2)} v\right)(\varphi)$ be the trigonometric interpolation polynomial for this function with the nodes $\left\{\varphi_{o j}^{(n)}\right\}_{j=0}^{2 n}$.

Below we use the function $\eta(x)= \begin{cases}1, & x>0 \\ 0, & x \leq 0\end{cases}$

Discretization of system of SIE (1) is carried out by the method of discrete singularities. The approximate solution $\vec{u}_{\bar{n}}=\left(u_{k n_{k}}\right)_{k=1}^{m}\left(\bar{n}=\left(n_{1}, \ldots, n_{m}\right)\right)$ to system $(1)$, where $u_{k n_{k}}(\tau)=\left(L_{n_{k}}^{\left(\lambda_{k}, 1\right)} u_{k}\right)(\tau)$ for $1 \leq k \leq m_{1}, u_{k n_{k}}(\varphi)=\left(P_{n_{k}}^{(1)} u_{k}\right)(\varphi)$ for $m_{1}+1 \leq k \leq m$, is found from the following system of SIE:

$$
\left\{\begin{array}{c}
\frac{1}{\pi} \int_{-1}^{1} \frac{u_{i n_{i}}(\tau) \rho_{\lambda_{i}}(\tau)}{\tau-t} d \tau+\sum_{k=1}^{m_{1}} \frac{1}{\pi} \int_{-1}^{1} Q_{i k n_{i} n_{k}}(t, \tau) u_{k n_{k}}(\tau) \rho_{\lambda_{k}}(\tau) d \tau+\sum_{k=m_{1}+1}^{m} \frac{1}{2 \pi} \int_{0}^{2 \pi} Q_{i k n_{i} n_{k}}(t, \varphi) u_{k n_{k}}(\varphi) d \varphi+ \\
+\eta\left(-\lambda_{i}\right) \beta_{i \bar{n}}=\left(L_{n_{i}-\lambda_{i}}^{\left(\lambda_{i}, 2\right)} f_{i}\right)(t), \quad i=1, \ldots, m_{1} \\
\frac{1}{2 \pi} \int_{0}^{2 \pi} \operatorname{ctg} \frac{\varphi-\theta}{2} u_{i n_{i}}(\varphi) d \varphi+\sum_{k=1}^{m_{1}} \frac{1}{\pi} \int_{-1}^{1} Q_{i k n_{i} n_{k}}(\theta, \tau) u_{k n_{k}}(\tau) \rho_{\lambda_{k}}(\tau) d \tau+\sum_{k=m_{1}+1}^{m} \frac{1}{2 \pi} \int_{0}^{2 \pi} Q_{i k n_{i} n_{k}}(\theta, \varphi) u_{k n_{k}}(\varphi) d \varphi+ \\
+\beta_{i \bar{n}}=\left(P_{n_{i}}^{(2)} f_{i}\right)(\theta), \quad i=m_{1}+1, \ldots, m,
\end{array}\right.
$$

supplemented by the conditions: 


$$
\left\{\begin{array}{c}
\frac{1}{\pi} \int_{-1}^{1} u_{k n_{k}}(\tau) \frac{d \tau}{\sqrt{1-\tau^{2}}}=0, \quad k=l_{2}+1, \ldots, m_{1} \\
\frac{1}{2 \pi} \int_{0}^{2 \pi} u_{k n_{k}}(\varphi) d \varphi=0, \quad k=m_{1}+1, \ldots, m
\end{array}\right.
$$

In (7) $\beta_{i \bar{n}}$ are the auxiliary regularization variables and the notation $Q_{i k n_{i} n_{k}}(\cdot, \cdot)$ stand for:

$$
\begin{array}{ll}
Q_{i k n_{i} n_{k}}(t, \tau)=\left(L_{n_{i}-\lambda_{i}, t}^{\left(\lambda_{i}, 2\right)} L_{n_{k}, \tau}^{\left(\lambda_{k}, 1\right)} Q_{i k}\right)(t, \tau), & 1 \leq i, k \leq m_{1} ; \\
Q_{i k n_{i} n_{k}}(t, \varphi)=\left(L_{n_{i}-\lambda_{i}, t}^{\left(\lambda_{i}, 2\right)} P_{n_{k}, \varphi}^{(1)} Q_{i k}\right)(t, \varphi), \quad 1 \leq i \leq m_{1}, m_{1}+1 \leq k \leq m ; \\
Q_{i k n_{i} n_{k}}(\theta, \tau)=\left(P_{n_{i}, \theta}^{(2)} L_{n_{k}, \tau}^{\left(\lambda_{k}, 1\right)} Q_{i k}\right)(\theta, \tau), & m_{1}+1 \leq i \leq m, 1 \leq k \leq m_{1} ; \\
Q_{i k n_{i} n_{k}}(\theta, \varphi)=\left(P_{n_{i}, \theta}^{(2)} P_{n_{k}, \varphi}^{(1)} Q_{i k}\right)(\theta, \tau), & m_{1}+1 \leq i, k \leq m .
\end{array}
$$

Let us discuss in some detail the essence of the regularization variables.

A straightforward replacement of all the functions in (1) by their interpolation polynomials results in a system of SIE with respect to $\vec{u}_{\bar{n}}$ for which, as a rule, the necessary conditions of solvability do not hold. This problem is resolved by introducing the regularization functions:

$$
\begin{aligned}
& \text { for } 1 \leq i \leq m_{1}, \quad f_{i \bar{n}}^{R}(t)=\left(L_{n_{i}-\lambda_{i}}^{\left(\lambda_{i}, 2\right)} f_{i}\right)(t)-\frac{\eta\left(-\lambda_{i}\right)}{\pi} \int_{-1}^{1}\left(L_{n_{i}-\lambda_{i}}^{\left(\lambda_{i}, 2\right)} f_{i}\right)(t) \frac{1}{\sqrt{1-t^{2}}} d t \\
& \qquad Q_{i k n_{i} n_{k}}^{R}(t, \zeta)=Q_{i k n_{i} n_{k}}(t, \zeta)-\frac{\eta\left(-\lambda_{i}\right)}{\pi} \int_{-1}^{1} Q_{i k n_{i} n_{k}}(t, \zeta) \frac{1}{\sqrt{1-t^{2}}} d t \\
& \text { for } m_{1}+1 \leq i \leq m, \quad f_{i \bar{n}}^{R}(\theta)=\left(P_{n_{i}}^{(2)} f_{i}\right)(\theta)-\frac{1}{2 \pi} \int_{0}^{2 \pi}\left(P_{n_{i}}^{(2)} f_{i}\right)(\theta) d \theta \\
& \qquad Q_{i k n_{i} n_{k}}^{R}(\theta, \zeta)=Q_{i k n_{i} n_{k}}(\theta, \zeta)-\frac{1}{2 \pi} \int_{0}^{2 \pi} Q_{i k n_{i} n_{k}}(\theta, \zeta) d \theta .
\end{aligned}
$$

Denote $\vec{f}_{\bar{n}}=\left(f_{i \bar{n}}\right)_{i=1}^{m}, \widehat{Q}_{\bar{n}} \vec{u}=\left(\sum_{k=1}^{m} Q_{i k n_{i} n_{k}} u_{k n_{k}}\right)_{i=1}^{m}, \vec{f}_{\bar{n}}^{R}=\left(f_{i \bar{n}}^{R}\right)_{i=1}^{m}, \widehat{Q}_{\bar{n}}^{R} \vec{u}=\left(\sum_{k=1}^{m} Q_{i k n_{i} n_{k}}^{R} u_{k n_{k}}\right)_{i=1}^{m}$.

Then using these notations system (7) is readily reduced to the following operator equation:

$$
\left(\widehat{A}+\widehat{Q}_{\bar{n}}^{R}\right) \vec{u}_{\bar{n}}=\vec{f}_{\bar{n}}^{R},
$$

supplemented by conditions (8).

Apparently, the regularization functions introduced above satisfy conditions (6). Hence, the necessary condition of solvability holds for equation (9).

Equation (9) can also be written in the form:

$$
\left(\widehat{A}+\widehat{Q}_{\bar{n}}\right) \vec{u}_{\bar{n}}+\vec{\beta}_{\bar{n}}=\vec{f}_{\bar{n}}
$$

with $\vec{\beta}_{\bar{n}}=\left(\beta_{i \bar{n}}\right)_{i=1}^{m}$,

$$
\left\{\begin{array}{c}
\beta_{i \bar{n}}=\frac{\eta\left(-\lambda_{i}\right)}{\pi} \int_{-1}^{1}\left[\left(L_{n_{i}-\lambda_{i}}^{\left(\lambda_{i}, 2\right)} f_{i}\right)(t)-\sum_{k=1}^{m}\left(Q_{i k n_{i} n_{k}} u_{k n_{k}}\right)(t)\right] \frac{d t}{\sqrt{1-t^{2}}}, \quad i=1, \ldots, m_{1} \\
\beta_{i \bar{n}}=\frac{1}{2 \pi} \int_{0}^{2 \pi}\left[\left(P_{n_{i}}^{(2)} f_{i}\right)(\theta)-\sum_{k=1}^{m}\left(Q_{i k n_{i} n_{k}} u_{k n_{k}}\right)(\theta)\right] d \theta, \quad i=m_{1}+1, \ldots, m .
\end{array}\right.
$$

The equalities defining $\beta_{i \bar{n}}$ are in fact the quadratures of the integrals found in the left-hand parts of conditions (5). Now we can conclude that problem (7), (8) is equivalent to problems (9), (8) and (10), (8).

Consider the equations of system (7), (8) with the numbers $i=1, \ldots, m_{1}$ at the points $\left\{t_{o p_{i}}^{\left(\lambda_{i}, n_{i}\right)}\right\}_{p_{i}=1}^{n_{i}-\lambda_{i}}$, and those with 
the numbers $i=m_{1}+1, \ldots, m$ at the points $\left.\left\{\varphi_{o j_{i}}^{\left(n_{i}\right.}\right)\right\}_{j_{i}=0}^{2 n_{i}}$ and compute the integrals using the quadrature formulae [8, 9]. Taking into account the equality of the values of a functions and its interpolation polynomial at the nodes of interpolation we arrive at a linear system of algebraic equations (SLAE) for the unknown functions $u_{i}\left(t_{r_{i}}^{\left(\lambda_{i}, n_{i}\right)}\right), 1 \leq r_{i} \leq n_{i}, 1 \leq i \leq m_{1} ; u_{i}\left(\varphi_{r_{i}}^{\left(n_{i}\right)}\right), 0 \leq r_{i} \leq 2 n_{i}, m_{1}+1 \leq i \leq m ; \beta_{i \bar{n}}, 1 \leq i \leq l_{1}, m_{1}+1 \leq i \leq m$, equivalent to system (7), (8). The SLAE obtained approximates system of SIE (1) supplemented by auxiliary conditions (4):

$$
\left\{\begin{array}{c}
\sum_{r_{i}=1}^{n_{i}} a_{r_{i}}^{\left(\lambda_{i}, n_{i}\right)}\left[\frac{1}{t_{r_{i}}^{\left(\lambda_{i}, n_{i}\right)}-t_{o p_{i}}^{\left(\lambda_{i}, n_{i}\right)}}+Q_{i i}\left(t_{o p_{i}}^{\left(\lambda_{i}, n_{i}\right)}, t_{r_{i}}^{\left(\lambda_{i}, n_{i}\right)}\right)\right] u_{i}\left(t_{r_{i}}^{\left(\lambda_{i}, n_{i}\right)}\right)+\sum_{\substack{k=1 \\
k \neq i}}^{m_{1}} \sum_{r_{k}=1}^{n_{k}} a_{r_{k}}^{\left(\lambda_{k}, n_{k}\right)} Q_{i k}\left(t_{o p_{i}}^{\left(\lambda_{i}, n_{i}\right)}, t_{r_{k}}^{\left(\lambda_{k}, n_{k}\right)}\right) u_{k}\left(t_{r_{k}}^{\left(\lambda_{k}, n_{k}\right)}\right)+ \\
\quad+\sum_{k=m_{1}+1}^{m} \sum_{r_{k}=0}^{2 n_{k}} \frac{1}{2 n_{k}+1} Q_{i k}\left(t_{o p_{i}}^{\left(\lambda_{i}, n_{i}\right)}, \varphi_{r_{k}}^{\left(n_{k}\right)}\right) u_{k}\left(\varphi_{r_{k}}^{\left(n_{k}\right)}\right)+\eta\left(-\lambda_{i}\right) \beta_{i \bar{n}}=f_{i}\left(t_{o p_{i}}^{\left(\lambda_{i}, n_{i}\right)}\right), p_{i}=1, \ldots, n_{i}-\lambda_{i} ; i=1, \ldots, m_{1} ; \\
\sum_{r_{i}=0}^{2 n_{i}} \frac{1}{2 n_{i}+1}\left[\operatorname{ctg} \frac{\varphi_{r_{i}}^{\left(n_{i}\right)}-\varphi_{0 j_{i}}^{\left(n_{i}\right)}}{2}+Q_{i i}\left(\varphi_{o j_{i}}^{\left(n_{i}\right)}, \varphi_{r_{i}}^{\left(n_{i}\right)}\right)\right] u_{i}\left(\varphi_{r_{i}}^{\left(n_{i}\right)}\right)+\sum_{k=1}^{m_{1}} \sum_{r_{k}=1}^{n_{k}} a_{r_{k}}^{\left(\lambda_{k}, n_{k}\right)} Q_{i k}\left(\varphi_{o j_{i}}^{\left(n_{i}\right)}, t_{r_{k}}^{\left(\lambda_{k}, n_{k}\right)}\right) u_{k}\left(t_{r_{k}}^{\left(\lambda_{k}, n_{k}\right)}\right)+ \\
+\sum_{k=m_{1}+1}^{m} \sum_{k \neq i}^{2 n_{k}} \frac{1}{2 n_{k}+1} Q_{i k}\left(\varphi_{o j_{i}}^{\left(n_{i}\right)}, \varphi_{r_{k}}^{\left(n_{k}\right)}\right) u_{k}\left(\varphi_{r_{k}}^{\left(n_{k}\right)}\right)+\beta_{i \bar{n}}=f_{i}\left(\varphi_{o j_{i}}^{\left(n_{i}\right)}\right), j_{i}=0, \ldots, 2 n_{i} ; i=m_{1}+1, \ldots, m, \\
\frac{1}{n_{k}} \sum_{r_{k}=1}^{n_{k}} u_{k}\left(t_{r_{k}}^{\left(\lambda_{k}, n_{k}\right)}\right)=0, \quad k=l_{2}+1, \ldots, m_{1} ; \quad \frac{1}{2 n_{k}+1} \sum_{r_{k}=0}^{2 n_{k}} u_{k}\left(\varphi_{r_{k}}^{\left(n_{k}\right)}\right)=0, \quad k=m_{1}+1, \ldots, m .
\end{array}\right.
$$

In (11) $a_{r_{k}}^{\left(\lambda_{k}, n_{k}\right)}$ are the coefficients of the quadrature formulae [8]:

$$
a_{r_{k}}^{\left(1, n_{k}\right)}=\frac{1}{n_{k}}, \quad a_{r_{k}}^{\left(0, n_{k}\right)}=\frac{4}{2 n_{k}+1} \sin ^{2}\left(\frac{r_{k} \pi}{2 n_{k}+1}\right), \quad a_{r_{k}}^{\left(-1, n_{k}\right)}=\frac{1}{n_{k}+1} \sin ^{2}\left(\frac{r_{k} \pi}{n_{k}+1}\right) .
$$

Note that system (11), (12) consists of $\sum_{i=1}^{m_{1}} n_{i}+2 \sum_{i=m_{1}+1}^{m} n_{i}+2\left(m-m_{1}\right)+l_{1}$ equations which number equals the quantity of its unknowns.

From the above it follows that system (11), (12) is equivalent to problem (7), (8) in the sense that the solutions $\vec{u}_{\bar{n}}=\left(u_{k n_{k}}\right)_{k=1}^{m}$ to problem (7), (8) coincide with the solutions to system (11), (12) at the interpolation nodes.

We prove below that starting from some $n=\min \left(n_{1}, n_{2}, \ldots, n_{m}\right)$ problem (7), (8), and, hence, problem (11), (12), admits a unique solution.

Main spaces and operators. In what follows we use the following spaces:

$L_{\rho[-1,1]}^{2}-$ the Hilbert space of functions on $[-1,1]$ endowed with the scalar product:

$$
(x, y)_{\rho}=\int_{-1}^{1} x(\tau) \bar{y}(\tau) \rho(\tau) d \tau ;
$$

$L_{40,2 \pi]}^{2}$ - the Hilbert space of $2 \pi$ - periodic functions with the scalar product given by:

$$
(x, y)=\int_{0}^{2 \pi} x(\varphi) \bar{y}(\varphi) d \varphi ;
$$

$\vec{L}_{I}^{2}$ - the Hilbert space of vector functions $\vec{x}=\left(x_{i}\right)_{i=1}^{m}, x_{i}=x_{i}(\tau) \in L_{\rho_{\lambda_{i}}[-1,1]}^{2}$ for $1 \leq i \leq m_{1}, x_{i}=x_{i}(\varphi) \in L_{00,2 \pi]}^{2}$ for $m_{1}+1 \leq i \leq m$ with the scalar product:

$$
(\vec{x}, \vec{y})_{I}=\sum_{k=1}^{m_{1}}\left(x_{k}, y_{k}\right)_{\rho_{\lambda_{k}}}+\sum_{k=m_{1}+1}^{m}\left(x_{k}, y_{k}\right) ;
$$

$\vec{L}_{I}^{2,0}-$ the subspace of $\bar{L}_{I}^{2}$ which elements satisfy (4); 
$\vec{L}_{I I}^{2}$ - the Hilbert space of vector functions $\vec{x}=\left(x_{i}\right)_{i=1}^{m} \quad x_{i}=x_{i}(t) \in L_{\rho_{\lambda_{i}}^{-1}[-1,1]}^{2}$ for $1 \leq i \leq m_{1}, x_{i}=x_{i}(\varphi) \in L_{10,2 \pi]}^{2}$ for $m_{1}+1 \leq i \leq m$ with the scalar product:

$$
(\vec{x}, \vec{y})_{I I}=\sum_{k=1}^{m_{1}}\left(x_{k}, y_{k}\right)_{\rho_{\lambda_{k}}^{-1}}+\sum_{k=m_{1}+1}^{m}\left(x_{k}, y_{k}\right) ;
$$

$\vec{L}_{I I}^{2,0}$ - the subspace of $\vec{L}_{I I}^{2}$ which elements satisfy the condition $\left(\vec{x}, \vec{e}_{k}\right)_{I I}=0$ for $1 \leq k \leq l_{2}$ and $m_{1}+1 \leq k \leq m$, where $\vec{e}_{k}=\left(\delta_{i k}\right)_{i=1}^{m}$ and $\delta_{i k}$ is the Kronecker symbol.

From [10] we know that both the characteristic equation $\left(A_{\lambda} x\right)(t)=y(t)$ supplemented by the auxiliary conditions $\eta(\lambda) \int_{-1}^{1} x(\tau) \rho_{\lambda}(\tau) d \tau=0$ as well as the characteristic equation $(\Gamma x)(\theta)=y(\theta)$ with the auxiliary condition $\int_{0}^{2 \pi} x(\varphi) d \varphi=0$ admit a unique solution if the respective assumption holds: either $\eta(-\lambda) \int_{-1}^{1} y(t) \rho_{\lambda}^{-1}(t) d t=0$ or $\int_{0}^{2 \pi} y(\theta) d \theta=0$. Consequently, the operator $\widehat{A}$ possesses a continuous inverse if restricted to the pair of spaces:

$$
\left(\bar{L}_{I}^{2,0}, \vec{L}_{I I}^{2,0}\right) \text {. }
$$

The operator $\widehat{Q}$ is completely continuous, hence, the unique solvability of problem (3), (4) implies that the operator $\widehat{A}+\widehat{Q}$ is continuously invertible in the pair of spaces (13).

Next we introduce a pair of finite dimensional functional spaces, which are subspaces of the main spaces $\vec{L}_{I}^{2}$ and $\bar{L}_{I I}^{2}$, and study the restriction of equation (9) to them.

Let $\Pi_{r}$ be the set of all algebraic polynomials which degree does not exceed $r-1$; let $\Phi_{r}$ denote the set of all trigonometric polynomials which order does not exceed $r$;

$$
\begin{gathered}
\bar{\Pi}_{I \bar{n}}=\left\{\vec{w}=\left(w_{k}\right)_{k=1}^{n}: \quad w_{k}(\tau) \in \Pi_{n_{k}} \text { for } 1 \leq k \leq m_{1}, \quad w_{k}(\varphi) \in \Phi_{n_{k}} \text { for } m_{1}+1 \leq k \leq m\right\} ; \\
\bar{\Pi}_{I I \bar{n}}=\left\{\vec{w}=\left(w_{k}\right)_{k=1}^{n}: \quad w_{k}(t) \in \Pi_{n_{k}-\lambda_{k}} \text { for } 1 \leq k \leq m_{1}, \quad w_{k}(\theta) \in \Phi_{n_{k}} \text { for } m_{1}+1 \leq k \leq m\right\} ; \\
\bar{\Pi}_{I \bar{n}}^{0}=\bar{L}_{I}^{2,0} \cap \bar{\Pi}_{I \bar{n}} ; \quad \bar{\Pi}_{I I \bar{n}}^{0}=\bar{L}_{I I}^{2,0} \cap \bar{\Pi}_{I I \bar{n}} .
\end{gathered}
$$

We study the restriction of equation (9) to the pair of spaces:

$$
\left(\bar{\Pi}_{I \bar{n}}^{0}, \bar{\Pi}_{I I \bar{n}}^{0}\right) \text {. }
$$

In this case conditions (8) apparently hold.

To prove that equation (9) admits a solution when considered in the pair of spaces (14) we need to estimate the values of $\left\|\left(\widehat{Q}-\widehat{Q}_{\bar{n}}^{R}\right) \vec{u}_{\bar{n}}\right\|_{I I}$ and $\left\|\vec{f}-\vec{f}_{\bar{n}}^{R}\right\|_{I I}$. Using the properties of the interpolation polynomials and Jackson's theorems [9] we arrive at the following result: if $n=\min \left\{n_{1}, \ldots, n_{m}\right\}$ then

$$
\left\|\left(\widehat{Q}-\widehat{Q}_{\bar{n}}^{R}\right) \vec{u}_{\bar{n}}\right\|_{I I} \leq \frac{1}{(n-2)^{\mu+\gamma}} M(Q)\left\|u_{\bar{n}}\right\|_{I}, \quad\left\|\vec{f}-\vec{f}_{\bar{n}}^{R}\right\|_{I I} \leq \frac{1}{(n-2)^{\mu+\gamma}} F(f),
$$

where $M(Q)$ and $F(f)$ are constants depending only on $Q$ and $f$.

We are now in position to use the following theorem from [11] describing the properties of an operator close to an invertible one:

Theorem 1. Let $X$ and $Y$ be linear normed spaces, and $\tilde{X} \subset X$ and $\tilde{Y} \subset Y$ be their finite dimensional subspaces such that $\operatorname{dim} \tilde{X}=\operatorname{dim} \tilde{Y}$. Consider the equations:

the exact one

$$
T x=y(x \in X, y \in Y)
$$

and the approximate one 


$$
\tilde{T} \tilde{x}=\tilde{y}(\tilde{x} \in \tilde{X}, \tilde{y} \in \tilde{Y}),
$$

where $T$ and $\tilde{T}$ are linear operators, $T: X \rightarrow Y, \quad \tilde{T}: \tilde{X} \rightarrow \tilde{Y}$.

If the following conditions hold:

a) the operator $T$ is continuously invertible in $(X, Y)$,

b) $p=\left\|T^{-1}\right\|_{Y \rightarrow X}\|T-\tilde{T}\|_{\tilde{X} \rightarrow \tilde{Y}}<1$,

then the approximate equation admits a unique solution $\tilde{x}^{*} \in \tilde{X}$ for any right-hand part $\tilde{y} \in \tilde{Y}$. Moreover, if $x^{*} \in X$ is the exact solution of the equation $T x=y$ and $\delta=\|y-\tilde{y}\|_{Y}$, then

$$
\left\|x^{*}-\tilde{x}^{*}\right\|_{X} \leq\left\|T^{-1}\right\|_{Y \rightarrow X}(1-p)^{-1}\left[\delta-p\|y\|_{Y}\right] .
$$

From estimates (15) and Theorem 1 it follows that for $n$ sufficiently large equation (9) admits a unique solution in the pair of spaces (14). Hence, the same is true for SLAE (11), (12). Moreover, the following estimate describing the rate of convergence of the approximate solution to the exact one holds:

$$
\left\|\vec{u}-\vec{u}_{\bar{n}}\right\|_{I} \leq \alpha_{\bar{n}}, \quad \text { where } \alpha_{\bar{n}}=O\left(n^{-\mu-\gamma}\right) \text { as } n \rightarrow \infty .
$$

We also provide estimates for the regularization variables:

$$
\text { for } 1 \leq i \leq l_{1} \text { and } m_{1} \leq i \leq m: \quad\left|\beta_{i \bar{n}}\right| \leq \sigma_{\bar{n}} \text {, where } \sigma_{\bar{n}}=O\left(n^{-\mu-\gamma}\right) \text { as } n \rightarrow \infty \text {. }
$$

Conclusions. The method of discrete singularities is applied for solving a specific system of first kind singular integral equations with the Hilbert and Cauchy kernels. The system of linear algebraic equations approximating the given system and auxiliary conditions is derived. It is proved that if the right-hand parts of the system of singular integral equations satisfy some smoothness conditions and the kernels are regular then for $n$ sufficiently large the approximating system of linear algebraic equations admits a unique solution. Moreover, the rate of convergence of the approximate solution to the exact one is estimated.

\section{Bibliography}

1. Белочерковский С. М., Лифанов И. К. Численные методы в сингулярных интегральных уравнениях и их применение в аэродинамике, теории упругости, электродинамике. - Москва : Наука, 1985. - 254 с.

2. Полянская Т. С. Математические модели задач дифракции Е-поляризованных волн на бесконечно тонких идеально проводящих решетках. // Труды XVI Международного симпозиума МДОЗМФ-2013. - Харьков-Херсон, 2013. - С. 326 - 328.

3. Polyanskaya T. S., Naboka $O$. O. Numerical solution of a singular integral equation with the Hilbert kernel by the method of discrete singularities. // Bulletin of the National Technical University «KhPI». Series : Mathematical modeling in engineering and technologies. - 2019. - no. 22 (1347). - pp. $89-94$.

4. Гандель Ю. В., Полянская Т. С. Обоснование численного метода решения систем сингулярных интегральных уравнений задач дифракции на решетках. // Дифференц. уравнения. - 2003. - Т. 39. - № 9- С. 1229 - 1239.

5. Гандель Ю. В., Полянская Т. С. Математические вопросы метода дискретных зарядов. Учеб. пособие. Ч.І. - Харьков, 1991. - 67 с.

6. Гандель Ю. В., Еременко С. В., Полянская Т. С. Математические вопросы метода дискретных токов. Учеб. пособие. Ч.ІІ. - Харьков, 1992. $-145 \mathrm{c}$.

7. Иванов В. В. Теория приближенных методов и ее применения к численному решению сингулярных интегральных уравнений. - Киев : Наукова думка, 1968. - 288 с.

8. Корнейчук A. А. Квадратурные формулы для сингулярных интегралов. - В кн.: Численные методы решения дифференциальных и интегральных уравнений и квадратурные формулы. - Москва : Наука, 1964, с. 64-74.

9. Натансон И. П. Конструктивная теория функций. - Москва - Ленинград : ГТТИ, 1949. - 688 с.

10. Гандель Ю. В. Лекции о численных методах для сингулярных интегральных уравнений. Учеб. пособие. Ч. 1. - Харьков - Херсон, 2001. $-92 \mathrm{c}$.

11. Габдулхаев Б. Г. Оптимальные аппроксимации решений линейных задач. - Казань : Изд. Казанск. ун-та, 1980. - 231с.

\section{References (transliterated)}

1. Belotserkovskiy S. M., Lifanov I. K. Chislennyye metody $v$ singulyarnykh integral'nykh uravneniyakh $i$ ikh primeneniye $v$ aerodinamike, teorii uprugosti, elektrodinamike [Numerical methods for singular integral equations and their application in aerodynamics, elastisity theory, electrodynamics]. Moscow, Nauka Publ., 1985. 254 p.

2. Polyanskaya T. S. Matematicheskiye modeli zadach difraktsii E-polyarizovannykh voln na beskonechno tonkikh ideal'no provodyashchikh reshetkakh [Mathematical models of the problems of diffraction of E-polarized waves on infinitly thin perfectly conducting grates]. Trudy XVI Mezhdunarodnogo simpoziuma MDOZMF-2013 [Proceedings of the XVI International Symposium MDSPMP-2013]. Kharkov-Kherson, 2013, pp. 326-328.

3. Polyanskaya T. S., Naboka O. O. Numerical solution of a singular integral equation with the Hilbert kernel by the method of discrete singularities. Bulletin of the National Technical University «KhPI». Series : Mathematical modeling in engineering and technologies. 2019, no. 22 (1347), pp. 89-94.

4. Gandel' Y. V., Polyanskaya T. S. Obosnovaniye chislennogo metoda resheniya sistem singulyarnykh integral'nykh uravneniy zadach difraktsii na reshetkakh [Substantiation of the numerical method for solving systems of singular integral equations in the problems of diffraction on grates]. Differents. Uravneniya [Differential equations]. 2003, vol. 39, np. 9, pp. 1229-1239. 
5. Gandel' Y. V., Polyanskaya T. S. Matematicheskie voprosy metoda diskretnykh zaryadov. Ucheb. posobie. Ch. I [Mathematical problems of the method of discrete charges. Tutorial. Part I]. Kharkov, Kharkov State University Publ., 1991. 67 p.

6. Gandel' Y. V., Eremenko S. V., Polyanskaya T. S. Matematicheskie voprosy metoda diskretnykh tokov. Ucheb. posobie. Ch. II [Mathematical problems of the method of discrete currents. Textbook. Part II]. Kharkov, Kharkov State University Publ., 1992.145 p.

7. Ivanov V. V. Teoriya priblizhennykh metodov i yeye primeneniya $k$ chislennomu resheniyu singulyarnykh integral'nykh uravneniy [Approximate methods theory and its application to numerical solving of singular integral equations]. Kiyev, Naukova dumka Publ., 1968. 288p.

8. Korneychuk A. A. Kvadraturnyye formuly dlya singulyarnykh integralov [Quadrature formulae for singular integrals]. In: Chislennyye metody resheniya differentsial'nykh $i$ integral'nykh uravneniy $i$ kvadraturnyye formuly [Numerical methods for solving differential and integral equations and quadrature formulae]. Moscow, Nauka, 1964. pp. 64-74.

9. Natanson I. P. Konstruktivnaya teoriya funktsiy [Constractive theory of functions]. Moscow -Leningrad, GTTI Publ., 1949. 688 p.

10. Gandel' Y. V. Lektsii o chislennykh metodakh dlya singulyarnykh integral'nykh uravneniy. Ucheb. posobie. Ch. I [Lectures on numerical methods for singular integral equations. Textbook. Part I]. Kharkov, V. N. Karazin Kharkov National University Publ., 2001. 92 p.

11. Gabdulkhaev B. G. Optimal'nye approksimatsii resheniy lineynykh zadach [Optimal approximation of solutions to linear problems]. Kazan, Izd. Kazanskogo. Universiteta Publ., 1980. 231 p.

Received (надійила) 09.01.2020

Відомості про авторів / Сведения об авторах / Information about authors

Полянська Тетяна Семенівна (Полянская Татьяна Семеновна, Polyanskaya Tatyana Semenovna) - кандидат фізико-математичних наук, доцент, Національний технічний університет «Харківський політехнічний інститут», м. Харків; тел.: (093) 921-97-17; e-mail: tpolyanskaya1 @ gmail.com.

Набока Олена Олексіївна (Набока Елена Алексеевна, Naboka Olena Oleksiyivna) - кандидат фізикоматематичних наук, доцент, Національний технічний університет «Харківський політехнічний інститут», м. Харків; тел.: (097) 961-81-16; e-mail: lena622651@ gmail.com.

UDC $621.039,519.65$

\section{T. V. POTANINA, O. V. YEFIMOV, G. L. KHAVIN}

\section{MODELING NPP POWER UNIT STEAM TURBINE INSTALLATION STEAM SEPARATOR- SUPERHEATER TEMPERATURE CHARACTERISTICS BY INTERVAL ANALYSIS METHODS}

The determination of the temperature characteristics of one of the significant elements of the wet-steam turbines of nuclear power units - the steam separator-superheater is considered: namely the construction of the dependence of the temperature of the heated steam at the outlet of the second stage on the changing load of the power unit. Modeling is carried out taking into account the error limitation without reliable information about its distribution. To evaluate the coefficients of empirical dependence, constructed according to the results of experimental data, it is proposed to use numerical methods of interval analysis. The interval approach allows building a refined tube, guaranteed to contain acceptable dependences of the temperature of the heated steam on the electric power of the power unit. In a situation of data uncertainty and limited errors, numerical methods of interval analysis allow creating models of processes and equipment of NPP units with the maximum possible correspondence to a real object.

Key words: equipment of NPP power units, steam separator-superheater, temperature characteristics, uncertainty, processing of experimental data, non statistical measurement errors, interval analysis, interval model.

\section{Т. В. ПОТАНІНА, О. В. СФІМОВ, Г. Л. ХАВІН \\ МОДЕЛЮВАННЯ ТЕМПЕРАТУРНИХ ХАРАКТЕРИСТИК СЕПАРАТОРА-ПАРОПЕРЕГРІВНИКА ПАРОТУРБІННОЇ УСТАНОВКИ ЕНЕРГОБЛОКА АЕС МЕТОДАМИ ІНТЕРВАЛЬНОГО АНАЛІЗУ}

Розглянуто визначення температурних характеристик одного із значущих елементів вологопарових турбін енергоблоків АЕС - сепараторапароперегрівника: побудова залежності від навантаження енергоблоку температури пари, що нагрівається, на виході 3 другого ступеня. Моделювання здійснюється з врахуванням обмеженості похибки вимірювань без вірогідної інформації про ії розподіл. Для оцінювання коефіцієнтів емпіричної залежності, що конструюється за результатами експериментальних даних, пропонується застосування чисельних методів інтервального аналізу. Інтервальний підхід дозволяє побудувати уточнену трубку, яка гарантовано містить припустимі залежності температури пари, що нагрівається від електричної потужності енергоблоку. В ситуації невизначеності даних та обмеженості похибок чисельні методи інтервального аналізу дозволяють створювати моделі процесів та устаткування енергоблоків атомних електростанцій з максимально можливою їх відповідністю реальному об'єкту.

Ключові слова: обладнання енергоблоків АЕС, сепаратор-пароперегрівник, температурні характеристики, невизначеність, обробка експериментальних даних, нестатистичні похибки вимірювань, інтервальний аналіз, інтервальна модель.

\section{Т. В. ПОТАНИНА, А. В. ЕФИМОВ, Г. Л. ХАВИН \\ МОДЕЛИРОВАНИЕ ТЕМПЕРАТУРНЫХ ХАРАКТЕРИСТИК СЕПАРАТОРА- ПАРОПЕРЕГРЕВАТЕЛЯ ПАРОТУРБИННОЙ УСТАНОВКИ ЭНЕРГОБЛОКА АЭС МЕТОДАМИ ИНТЕРВАЛЬНОГО АНАЛИЗА}

Рассмотрено определение температурных характеристик одного из значимых элементов влажнопаровых турбин энергоблоков АЭС - сепаратора-пароперегревателя: построение зависимости температуры нагреваемого пара на выходе из второй ступени от изменяющейся нагрузки энергоблока. Моделирование выполняется с учетом ограниченности погрешности измерений без достоверной информации о ее распределении. Для оценивания коэффициентов эмпирической зависимости, конструируемой по результатам экспериментальных данных, предлагается применение численных методов интервального анализа. Интервальный подход позволяет построить уточненную трубку, гарантиро-

(C) T. V. Potanina, O. V. Yefimov, G. L. Khavin, 2020

Вісник Національного технічного університету «ХПІ».Серія: Математичне

моделювання в технійі та технологіях, № 1 (1355) 2020. 